\title{
Basel II Kriterlerinin Reel Sektöre Etkileri ve Basel III Kriterlerinin Bankalar Üzerine Etkilerinin Araştırılması
}

\author{
A Survey On The Effects Of Basel II On Real Sector and The Effects Of Basel III On \\ Banking Sector
}

\author{
Ahmet DOGAN * \\ Hatice ILLEEZ**
}

$\ddot{O} Z$

Çalışmanın amacı, Basel II Kriterlerinin ülkemizdeki reel sektöre muhtemel etkileri ile Basel III Kriterlerinin bankalar üzerindeki etkilerini araştırmaktır. İstanbul Sanayi Odası'nın yayınladı̆̆ ilk 1000 firma arasındaki Kayseri'deki 30 firmanın soru formu ve birebir görüşme yoluyla 17'sinden elde edilen veriler SPSS programı kullanılarak değerlendirilmiştir. Reel sektörün Basel II'ye bakış açısı konusunda firmaların Basel II'den beklentilerinin, kısa vadede \%82,4 'ünün olumlu, Orta ve uzun vadede ise bütün firmaların olumlu beklentileri olduğu sonucuna ulaşılmıştır. Basel II Kriterlerinde risk yönetimi önemli bir konudur. Firmaların \%23,5'i risk yönetimi bölümünün olduğunu, \%76,5'i risk yönetimi bölümünün olmadığını belirtmiştir. Bankacılık sektörünün Basel III Kriterlerinden Sermaye Yeterlilik Oranı, Likidite ve Kârlılık oranlarl konularında etkilendiği belirlenmiştir. Türkiye’de faaliyet gösteren aktif büyüklü̈̆̈̈ sıralamasındaki ilk beş bankanın finansal tablolarından yararlanılarak analizler yapılmıştır. Analizler sonucunda Basel III'ün oran kriterlerine bankaların uyumlu olduğu ve sektör ortalamalarının genellikle üzerinde oldukları tespit edilmiştir. Bu bankaların Basel III'e hazır oldukları görülmüştür.

\section{ANAHTAR KELIMELER}

Basel II, Basel III, Reel Sektör, Bankacıllk Sektörü

\begin{abstract}
The aim of the study is to investigate the effects of Basel II on the real sector and the effects of Basel III on banking. The survey was applied to 30 Kayseri firms in the first 1000 firms published by Istanbul Chamber of Industry. Results obtained from 17 firms were evaluated by using SPSS program. It is seen that firms' expectations from Basel II are positive in the short term regarding the perspective of real sector to Basel II. Risk management at Basel II is an important issue. $23.5 \%$ of the firms stated that there is a risk management department and $76.5 \%$ of them do not have a risk management department. It is determined that the banking sector is affected by Basel III on Capital Adequacy Ratio, Liquidity and Profitability ratios. The top five banks in terms of total assets operating in Turkey are analyzed using the financial statements. As a result of the analyzes, it is determined that banks are compatible with the ratio criteria of Basel III and they are generally above the sector average. These banks were found to be ready for Basel III.
\end{abstract}

\section{KEYWORDS}

Basel II, Basel III, Real Sector, Banking Sector

\begin{tabular}{|c|c|c|}
\hline \multicolumn{2}{|c|}{ Makale Geliş Tarihi / Submission Date } & \multicolumn{1}{c|}{$\begin{array}{c}\text { Makale Kabul Tarihi / Date of Acceptance } \\
\text { 27.03.2019.05.2019 }\end{array}$} \\
\hline \multirow{3}{*}{ Atıf } & $\begin{array}{l}\text { Doğan, A. ve İlleez, H. (2019). Basel II Kriterlerinin Reel Sektöre Etkileri ve Basel III Kriterlerinin Bankalar Üzerine } \\
\text { Etkilerinin Araştırılmas1. Selçuk Üniversitesi Sosyal Bilimler Meslek Yüksekokulu Dergisi, 22 (2), 459-468. }\end{array}$ \\
\hline
\end{tabular}

\footnotetext{
* Dr. Öğr. Üyesi, Erciyes Üniversitesi, İktisadi ve İdari Bilimler Fakültesi, adogan@erciyes.edu.tr, ORCID: 0000-0001-9311-9796

** Öğr. Gör., Nevşehir Hacı Bektaș Veli Üniversitesi, Meslek Yüksekokulu, hatice.hassu @ nevsehir.edu.tr, ORCID: 0000-0003-3192-0531
} 


\section{GİRIŞ}

Dünya çapında yaşanan krizler dünya ekonomilerini etkilemektedir. Bu nedenle uluslararası bir komite olan Bank for International Settlements-BIS (Uluslararası Ödemeler Bankası) kurulmuştur. Komite uluslararası özellikte olması nedeniyle birçok ülkede bankaların uyum sağlaması amacıyla belirli Kriterler geliştirmiştir. Bankacılık krizlerinin en önemli nedeni olarak sermayeye yeteri kadar önem verilmediğine dikkat çekilmiştir. Öncelikle sermaye yeterliliği hesaplaması konusunda çalışmalar yapılmıştır.

$\mathrm{Bu}$ çalışmalar daha sonra Sermaye Uzlaşısı- Basel I olarak yayınlanmıştır. Basel I Kriterleri ülke ve banka otoritelerinden destek görmesine rağmen birçok eleştiri de almıştır. Kriterler yeniden gözden geçirilerek Yeni Basel Sermaye Uzlaşısı- Basel II adında düzenlemeler yapılmıştır.

2008 yılına gelindiği zaman dünya da yaşanılan bir kriz ortamı oluşmuştur. Bu krizde Basel II düzenlemelerinin bankacılık sistemini yeteri kadar koruyamadığı ortaya çıkmıştır. Basel komitesi eksiklikleri gidermek için çalışmalara başlamış ve Basel III düzenlemeleri adını vermiş olduğu çalışmasını 2010 yılında tamamlamıştır. Basel III düzenlemeleri ana hatlarıyla sermayenin nitelik ve nicelik bakımından güçlendirilmesi ve risk bazlı olmayan kaldıraç oranı ile ilgili yenilikler içermektedir. Türkiye'de Basel III düzenlemeleri için aşamalı bir geçiş süreci öngörülmüşs ve tam olarak uygulanması 2019 yılı olarak belirlenmiştir.

$\mathrm{Bu}$ çalışmada önce Basel II ve Basel III hakkında kuramsal bilgiler verildikten sonra Basel II'nin reel sektöre etkileri ve Basel III'ün bankacılık sektörüne etkileri ile ilgili yaptığımız araştırmalara ve sonucunda elde edilen verilere yer verilecektir.

\section{KAVRAMSAL ÇERÇEVE}

Basel Komitesi, "Bankacılık Düzenleme ve Denetim Uygulamaları Komitesi” olarak 1974 yılı sonunda kurulmuştur. Denetimin dünya çapında geliştirilmesi, bankacılık denetim kalitesinin artırılması amaçlanmaktadır (Beşinci, 2005).

Bankacılık sektörünü ilgilendiren Basel uygulamalarının temeli ilk olarak 1988 yılında yayınlanan Basel I Kriterlerine dayanır. Basel I Kriterleri değişen piyasa şartlarına uyum sağlayamamaya başlayınca, Basel II'ye son hali Haziran 2004 tarihinde verilmiştir.

Basel I'e kıyasla sermaye yeterliliği hesaplamalarında köklü değişiklikler getiren Basel II Kriterlerinin, Şekil-1'de gösterilen temel yapısı, yapısal bloklardan oluşan üç sacayağı olarak ifade edilmektedir (Yüksel, 2005)

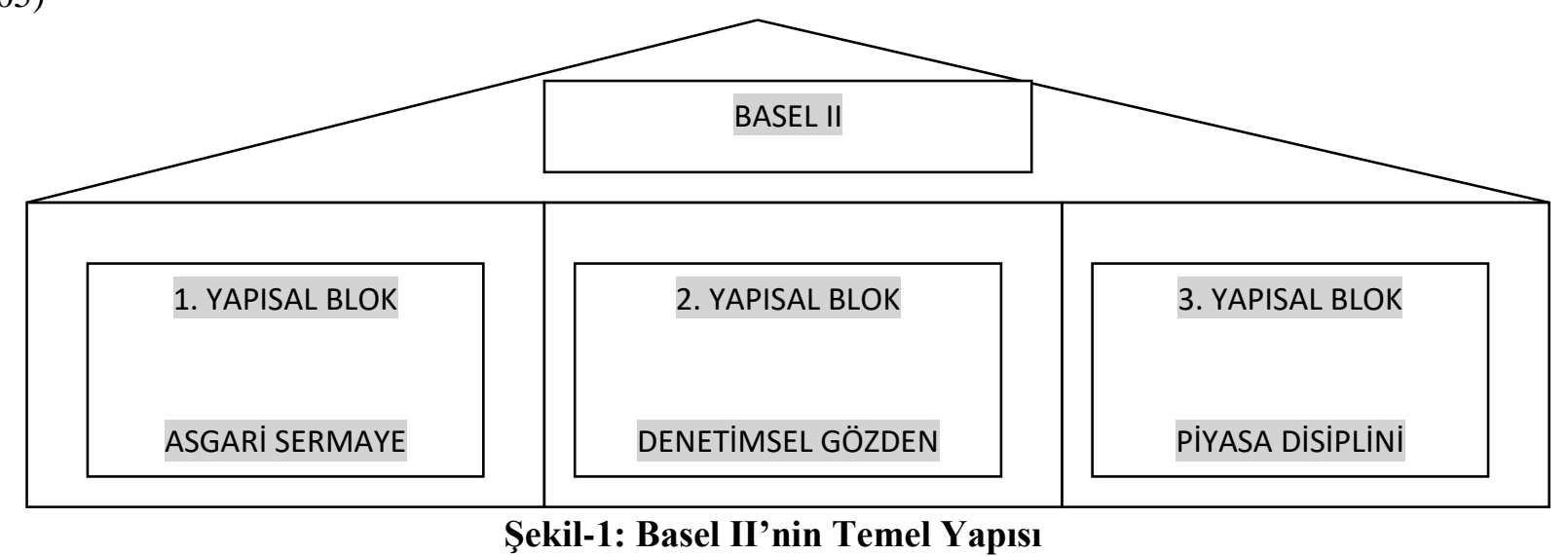

1. Yapısal Blok: Bankalar piyasa koşullarına hazırlanırken asgari sermayelerini belirleyeceklerdir. Basel I'deki sermaye tanımı değişmemiş ve asgari sermaye yeterlilik oranı (ASYO) yüzde 8 olarak aynen geçerli olmuştur. ASYO'nun paydası önemli şekilde değiştirilmiştir. Kredi riski daha detaylı tanımlanıp, piyasa riskinde değişiklik yapılmamış ve operasyonel risk eklenmiştir (Ateş, 2003).

$$
\text { Sermeye Yeterlilik Rasyosu }=\frac{\text { Toplam Sermaye }}{\text { Kredi Riski + Piyasa Riski + Operasyonel Risk }}
$$

2. Yapısal Blok: Basel Komitesi gözetimin kapsamını daha genişletmiştir. Gözetim kapsamının genişletilmesinin amacı; bankaların oluşacak riskleri karşılayabilecek düzeyde sermaye bulundurmalarını ve riskleri yönetmek için gelişmiş teknikleri kullanmalarını sağlamaktır. Sermaye, risk kontrol mekanizmaları için ikame olmayıp, dahili limitler uygulanmalıdır. Risk yönetiminin güçlendirilmesi için karş1ık seviyelerinin yükseltilip, iç kontrollerin arttırılması gerektiği özellikle vurgulanmalıdır (Ziraat Bankası, 2005). 
3. Yapısal Blok: Bankaların sermaye yeterliliği ile risk değerlendirme yöntemleri dahil olmak üzere önemli konularda kamuya açıklama yapmalarının gerektiğini belirtmektedir. Bankalar arasında karşılaştırma yapılabilmesi ve bu yolla şeffaflığın sağlanması hedeflenmektedir. Sermaye yapısı, portföy yapısı ve riskler dikkate alınarak, sermaye yeterliliği, kredi riski, hisse senedi şeklinde yapılan yatırımların riski, piyasa riski gibi faktörlerin kamuya açıklanması beklenmektedir (Küçüközmen, 2007).

$\mathrm{Bu}$ bloklar incelenirken; kredi riski, piyasa riski ve operasyonel riske dikkat edilecektir.

Basel II Kriterleri, gerek kapsamı gerekse içeriğindeki teknik hususlar dikkate alındığında uluslararası bir kriter olarak, bankacılık faaliyetlerinin düzenlenmesi ve denetlenmesi açısından köklü değişiklikler getirmektedir. Basel II'nin, bankalar ve bankacılık denetim otoritelerine, bankalar ile iş ilişkisinde bulunan tüm taraflara ve ülke ekonomilerine önemli etkilerinin olması beklenmektedir. Basel II Kriterlerinin en çok etkilediği taraf küçük ve orta büyüklükteki firmalar olmaktadır (Yüksel, 2005).

Küçük ve orta büyüklükteki işletmelerin (KOBİ) finansman kaynaklarının ilk sırasında özkaynaklar yer almaktadır. Özkaynakları güçlü firmalar finansman açısından avantajlı konumdadır. Firmaların özkaynaklarından sonra banka kredilerinin yer aldığını söyleyebiliriz. Bu durumda özkaynak yetersizliğinde firmalar banka kredilerine başvurdukları için bankaların yaşadığı değişimden etkilenmektedirler.

Öncelikle firmaların portföyleri belirlenmelidir. Perakende portföy firmaları için KOBİ kredileri \%75, kurumsal portföy firmaları için \%100 risk ağırlığına tabi tutulup, ASYO’nun \%8 olarak belirlenmesi sağlanmaktadır.

Teminat veya garantinin olmadığı durumlarda, Standart Yaklaşım'da \%75 standart risk ağırlığı perakende nitelikli krediler için, \%0-\%150 aralığındaki risk ağırlıkları ise derecelendirme notuna göre kurumsal KOBİ kredileri için uygulanmaktadır. İçsel Derecelendirmeye Dayalı yaklaşımlarda ise, KOBI'lerin derecelendirme notlarına dikkat edilerek risk ağırlıkları belirlenmektedir. Basel II'de KOBİ'lere sağlanan krediler ile büyük ölçekli firmalara sağlanan krediler farklı uygulamalara tabi tutulabilmektedir. Perakende KOBI'ler genel risk ağırlıkları dikkate alındığında daha avantajlı olabilmektedir (Yüksel, 2005).

KOBİ'lerin avantajlı faiz oranları ile krediye ulaşabilmesi için öncelikle derecelendirme gerekleri yerine getirilmelidir. KOBİ'lerin iyi bir derecelendirme notuna ve güçlü bir mali yapıya sahip olmaları gerekmektedir. Basel II'den avantajlı bir şekilde yararlanabilmeleri için KOBI'ler dikkat etmeleri gereken konuları iyi bilmelidirler. Bu durumlarda Basel II KOBI'ler için faydalı olabilecektir.

Yüksel (2005) tarafından yapılan çalışmada, Basel II'nin KOBİ kredileri ile ilgili hükümleri açıklanmış ve Basel II'nin KOBİ kredilerine muhtemel etkileri analiz edilmiştir. Yüksel'e göre, Basel II ile birlikte KOBI'lerin avantajlı şekilde kredi kullanabilmeleri için kredi derecelendirme sistemlerini iyi bilmeleri ve iyi bir derecelendirme notuna sahip olabilmek için gerekli adımları atmaları gerekmektedir. KOBI'lerin kurumsal yönetim, şeffaflık, finansal planlama, muhasebe işlemlerinde düzen ve risk yönetimi unsurlarına dikkat etmeleri gerekmektedir.

Yayla ve Kaya (2005:25) tarafından hazırlanan çalışma raporunda ise, Basel II detaylı şekilde açıklanmış ve gelişmekte olan ülkelere, genel ekonomiye ve KOBİ'lere muhtemel etkileri ele alınmıştır. Bu çalışmada da, KOBI'lerin Basel kriterlerinden olumsuz etkilenmelerini önlemek için kurumsal yönetim ilkelerine önem vermeleri, daha şeffaf bilançolar oluşturmaları ve uluslararası muhasebe standartlarını uygulamaları beklenmektedir.

Balcı (2011) çalışmasında, Basel II ve KOBİ UFRS arasındaki bağlantıyı incelemektedir. Basel II ile gelen değişim ile finans, üretim, planlama ve kurumsal yönetim konularına KOBİ'lerin önem vermelerinin gerektiği ve KOBİ'lerin yüksek derecelendirme notu alabilmek için KOBİ UFRS'yi uygulayarak kaliteli ve şeffaf finansal bilgiler üretmeleri gerektiği belirtilmektedir.

Sungur ve Okur (2014:18) tarafindan yapılan çalışmada, Ankara ilindeki KOBİ'lerin Basel kriterleri hakkında bilgi sahibi olmadığı, özkaynak yapılarının zayıf olduğu, mali tablolarının derecelendirmeye uygun olmadığı ve Basel kriterlerine uyumu zorlaştıracak kayıt dışı işlemlerin bulunduğu belirlenmiştir.

Bartolini ve diğ. (2014:51) ise, Basel kriterleri ile KOBİ UFRS'nin firmaların kredi derecelendirme notu üzerinde farklı etkisi olacağını ortaya koymuşlardır. Bartolini vd. İtalya'da bulunan firma üzerinde araştırma yapmış olup, varlık, özkaynak ve gelir üzerinde KOBİ UFRS'nin etkili olduğunu belirlemişlerdir. Ancak bu etki üzerinde finansal tabloların daha belirleyici olduğunu ve bankaların içsel derecelendirmelerini muhasebe etkisine göre ayarlamamaları gerektiğini belirtmektedirler.

2007-2008 yıllarında Amerika'da başlayan, gelişmiş ekonomilerde etkisini hissettiren finansal kriz kısa zamanda tüm dünyaya yayılmıştır. Basel II Kriterlerinin eksikleri ortaya çıkmış olup, piyasa şartları bozulduğunda Basel II kriterlerinin yetmediği ortaya konulmuştur (Şendoğdu, 2010). 
Dünya genelinde büyük kayıplara yol açan uluslararası kriz nedeniyle bankaların sermaye tutma yoluyla iflas etmelerinin önüne geçilmesini amaçlayan Basel II Kriterlerinin hedefine ulaşamadığ görülmüştür. (Demirkol ve Aba, 2012:262).

Bankaların daha dirençli olması için daha güçlü sermaye yapısı ve daha yüksek likidite gibi olguların üzerinde duran Basel Komitesi, Basel III Sermaye Uzlaşısını oluşturmuştur.

Basel III Uzlaşısı, yeni bir düzenleme olmayıp, Basel II'nin finansal kriz ile ortaya çıkan eksikliklerini gidermek için hazırlanan, Basel II'nin eksik yanlarını tamamlayacak reformlarlar bulundurmaktadır (Demirkol ve Şenbayram, 2014:247).

Basel III Kriterleri ile hedeflenen; mikro-ihtiyatl111k ve makro-ihtiyatl111ktır. Mikro-ihtiyatl1l1k bankalara esneklik kazandıracaktır. Makro-ihtiyatlılık ise riskleri küresel ortamda azaltacaktır. Basel III, küresel sonuçlar ile birlikte bölgesel faaliyetleri hedeflemektedir (Dedu \& Nitescu, 2012:6).

Basel III Kriterleri, temel finansman kaynağı banka kredileri olan firmaları ve bankaları etkileyecektir. Basel III Kriterleri ile bankalar, gerek bağımsız derecelendirme kuruluşları gerekse içsel derecelendirme yöntemleri ile belirlenen derecelendirme notuna göre kredi kullananlar için belirli miktarda sermaye ayırmak durumunda kalmaktadırlar.

Basel III, sermayenin yeniden tanımlanarak içindeki kalemlerin sınıflandırılması ve risklerin karşılanmasıyla ilgili değişikliklerden ibarettir. Risk kapsamındaki değişiklikler bazı teknik farklılıklar getirse de yeni ortaya çıkan riskler halen göz ardı edilmiştir.

Basel III ile uygulanmaya çalışlan en önemli değişiklik, sermaye koruma tamponunun hayata geçirilmesidir. $\mathrm{Bu}$ sayede ileriki dönemlerde güçlü sermaye yapısı ile bankalar aktif rol oynayabilecek, oluşan belirsizliklerin önüne geçebilecektir (Doğan ve Sarsıc1, 2018:115).

Basel III Kriterleriyle şu hedeflere ulaşlmak istenmektedir (Cangürel ve diğerleri, 2010:11):

- Bankacılık sisteminin finansal ve ekonomik şoklara karşı daha dayanıklı olunması,

- Risk yönetimi ve kurumsal yönetişim uygulamalarının geliştirilmesi,

- Kamuya bilgi verme ve şeffaflık özelliklerinin bankalarda artırılması,

- Mikro bazda yapılan düzenlemelerle bireysel olarak bankaların dayanıklılı̆̆ının artırılması,

- Makro bazda düzenlemelerle finansal sistemin şoklara karşı direncinin artırılmasıdır.

\section{ARAŞTIRMALARIN TANITIMI}

\subsection{BASEL II-Reel Sektör}

a) Kapsamı: KOBI'lerin Basel II Kriterleri hakkında ne kadar bilgi sahibi oldukları, ne tür hazırlık yaptıkları, bakış açıları ve beklentilerinin neler olduğu değerlendirilmiştir.

b) Araştırmanın Yöntemi: Araştırmamızda İstanbul Sanayi Odası'nın en büyük 1000 firma sıralamasındaki 30 adet Kayseri firmasından 17 adetine uygulanan soru formu ve birebir görüşme yoluyla elde edilen veriler SPSS programı kullanılarak değerlendirilmiştir. Soru formunda 23 adet soru vardır. Soru formunun ilk 8 sorusu firmaların genel bilgilerini içermektedir. Diğer sorular ise Basel II konuları ile ilgilidir. Soru formu çalışmasında sıralama soruları, açık uçlu sorular ve kategori soruları mevcuttur.

c) Kısıtları: Araştırmanın kısıtı sadece Kayseri ilinin esas alınmasıdır. İleride yapılacak araştırmalar farklı illerde uygulanabilir.

\subsection{BASEL III-Bankacılık Sektörü}

a) Kapsamı: Türkiye'de faaliyette bulunan bankaların Basel III Kriterleri çerçevesinde Sermaye Yeterlilik Oranları, Ortalama Aktif Kârlılı̆̆ı, Ortalama Özkaynak Kârlılığı değerlendirilmiştir.

b) Araştırmanın Yöntemi: Türkiye Bankalar Birliği'nin İstatistiki Raporlarından yararlanılarak Türkiye'deki aktif büyüklüğü en fazla olan beş bankanın son beş yıllık (2013-2017)*** oran analizleri elde edilmiştir.

c) Kısıtları: Araştırmada sadece 5 bankanın incelenmesi kısıt oluşturur. Diğer bankaların da ilerde yapılacak araştırmalarda incelenmesi mümkündür.

\footnotetext{
*** 2018 yıl sonu verileri çalışmamız sürecinde yayınlanmadığı için 2017 yıl sonu verileri kullanılmıştır.
} 


\section{BULGULAR}

\subsection{BASEL II- Reel Sektör}

Soru formuna katılan firmaların 14 adeti anonim şirket, 3 adeti limited şirkettir ve ayrıca bu firmalardan 2 adeti halka açık firmadır. Firmaların faaliyet süreleri incelendiğinde; soru formunu cevaplandıran firmaların $\% 41,2$ 'sinin faaliyet süresi 31 yıl veya üzerindedir. Bu durumda soru formunun uygulandı̆̆ firmaların $\% 47,1$ 'inin köklü firmalar olduğu Tablo 1'de görülmektedir.

\section{Tablo 1. Verilerin Özet Tablosu}

\begin{tabular}{|l|l|l|}
\hline İşletmenin Faaliyet Süresi & Firma Sayısı & Yüzde (\%) \\
\hline $3-5$ yıl & 1 & 5,9 \\
\hline $21-30$ yıl & 1 & 5,9 \\
\hline $6-10$ yıl & 3 & 17,6 \\
\hline $11-20$ yıl & 5 & 29,4 \\
\hline 31 yıl ve üzeri & 7 & 41,2 \\
\hline Toplam & 17 & 100 \\
\hline İşletmede Çalışıtırılan Kişi Sayısı & Firma Sayısı & Yüzde (\%) \\
\hline $50-250$ kişi & 1 & 5,9 \\
\hline 251 kişi ve üzeri & 16 & 94,1 \\
\hline Toplam & 17 & 100 \\
\hline Aktif Büyüklükleri & Firma Sayısı & Yüzde (\%) \\
\hline 501 milyon TL ve üzeri & 1 & 5,9 \\
\hline $91-120$ milyon TL & 2 & 11,8 \\
\hline $61-90$ milyon TL & 3 & 17,6 \\
\hline $121-200$ milyon TL & 3 & 17,6 \\
\hline $31-60$ milyon TL & 4 & 23,5 \\
\hline $201-500$ milyon TL & 4 & 23,5 \\
\hline Toplam & 17 & 100 \\
\hline Net Satıs Hasılatları & Firma Sayısı & Ÿ̈zde (\%) \\
\hline 501 milyon TL ve üzeri & 1 & 5,9 \\
\hline $61-90$ milyon TL & 2 & 11,8 \\
\hline $91-120$ milyon TL & 2 & 11,8 \\
\hline $121-200$ milyon TL & 3 & 17,6 \\
\hline $201-500$ milyon TL & 4 & 23,5 \\
\hline $31-60$ milyon TL & 5 & 29,4 \\
\hline Toplam & 17 & 100 \\
\hline & & \\
\hline
\end{tabular}

Soru formunun ikinci sorusu olan firmada çalıştırılan kişi sayısına firmaların \%94,1'inin cevabı 251 kişi ve üzeri iken \%5,9'unun cevabı 50-250 kişi arası olmuştur. İşletmelerin tamamına yakını 250 kişinin üzerinde kişi çalıştırmaktadır. Bu durum firmalardan biri haricindekilerin istihdam gücünün yüksek olduğunu göstermektedir.

İşletmelerin net satış hasılatlarının sorulduğu üçüncü soruda alınan cevaplara göre net satış hasılatlarının en çok 31-60 milyon TL ve 201-500 milyon TL aralığında firmaların yoğunlaştığı görülmektedir. Firmaların aktif büyüklükleri incelendiğinde 31-60 milyon TL ve 201-500 milyon TL aralığında firmaların yoğunlaştığı görülmektedir.

Finansal sorunların sıralanmasının istendiği 5. soruda firmaların derecelendirdikleri sorunların ortalamalarına göre dağılımı incelendiğinde firmalar en önemli sorun olarak maliyetlerin yüksekliğini belirtirken 2. önemli sorun olarak vadeli satışların çokluğunu ve 3. önemli sorun olarak da alacakların zamanında tahsil edilememesi sorununu belirtmişlerdir. Diğer sorunlar sırasıyla; uygun faizde kredi temin edememe, döviz kurlarındaki dalgalanma, öz kaynak yetersizliği, ticari kredilerin vadelerinin kısalı̆̆ı, gerekli yatırımların yapılamaması, işletme sermayesinin yetersizliği ve diğer nedenlerdir. Ülkemizin genel sorunu haline gelen maliyetlerdeki yüksekliğin devam ettiği bu soru ile açıkça ortaya konmuştur. 
Firmaların kredi kullanıp kullanmadıkları sorulduğunda, firmaların hepsi kredi kullandıklarını belirtmişlerdir. Bu firmaların 14 adeti $0-12$ ay vadeli kredileri kullandığını beyan etmiştir. Bu durumda firmaların genelde kısa vadeli kredileri tercih ettikleri söylenebilir. Bu durum firmaların Basel II açısından değerlendirilmesinde olumlu etki yapmaktadır. 0-12 ay vadeli kredi kullanmayıp uzun vadeli krediyi tercih eden firmaların da açıklamalarında yatırıma ağırlık verdikleri tespit edilmiştir.

Firmaların finansman kaynağı olarak en çok öz kaynakları, banka ticari kredilerini ve son olarak da teşvikli kredileri kullandıkları görülmüştür. Firmalar daha sonra sırasıyla teşvikli kredileri, özel finans kurumlarını, vadeli çek-senedi, satıcı kredilerini, faizsiz bankacılığı ve gayrimenkul satışlarını tercih etmiştirler. Firmalar, eş-dost-akraba ve dışındaki hiçbir kaynağı kullanmadıklarını belirtmişlerdir. Özkaynaklardan sonra banka ticari kredilerinin yoğun kullanıldığının belirtilmesi neticesinde teminatlar konusunda firmaların zorluk yaşayacağı aşikardır. Hem firmalar banka ticari kredilerini kullanırken hem de teminat gösterirken sıkıntı yaşayacaklardır.

Basel II hakkında firmaların bilgisinin olup olmadığı sorulduğunda 16 firma bilgilerinin olduğunu belirtirken 1 adet firma bilgilerinin olmadığını belirtmiştir. Basel II Kriterlerinde en önemli noktanın firmaların büyüklüklerine göre ayrılması konusu olduğu düşünüldüğü için firmaların büyüklüklerini sınıflandırmaları istenmiştir.

Basel II tanımlamalarına göre, 3 adet firmanın perakende KOBİ olduğu, 4 adet firmanın kurumsal KOBİ olduğu ve 10 adet firmanın da bu sınıflandırmadan farklı olarak kurumsal firma oldukları ortaya çıkmıştır. İstanbul Sanayi Odası (İSO), her yıl Türkiye'nin ilk 500 ve ikinci 500 büyük firmalarını yayınlamaktadır. Hizmet sektörü firmalarını içermese de Türkiye ekonomisinin durumu hakkında bilgi verecek yararlı bir araçtır. İSO sıralamasında satışları 50 milyon €'yu geçen firmaların sayısı 2003 yılında 299 iken 2017 yılında 774 olmuştur. Bu nedenle 774 firma KOBİ olarak değerlendirilemeyecektir.

Basel II Kriterlerinde risk yönetimi önemli bir konudur. Firmalara risk yönetimi bölümlerinin olup olmadığını sorduğumuzda aldığımız cevaplara göre firmaların \%23,5'i risk yönetimi bölümünün olduğunu, \%76,5'i risk yönetimi bölümünün olmadığını belirtmiştir. Yapılan incelemelerde risk yönetimi bölümünün olduğunu belirten firmaların 3 adetinde kredi riski, likidite riski ve kur riski bölümlerinin hepsi mevcutken 1 adetinde sadece kredi riski bölümünün mevcut olduğu tespit edilmiştir.

Firmaların iç denetim birimleri sorgulandığında firmaların verdikleri cevaplara göre firmaların 13 adetinde iç denetim biriminin olduğu, 4 adetinde olmadığı görülmektedir. Bu durum Basel II Kriterleri açısından firmalara avantaj sağlayacaktır. Alınan cevaplara göre 11 adet firmada 3 ayda bir iç denetim yapılırken, 1 adet firmada 6 ayda bir ve 1 adet firmada da yılda bir iç denetim yapılmaktadır. Süreler iç denetim için uygun sürelerdir. İç denetim uygulamayan firmalar için sıkıntılar olabileceğini belirtmekte yarar vardır.

Firmaların çoğunluğunda iç denetim mevcuttur. Bağımsız dış denetim hakkında bilgi edinmek istediğimizde firmaların \%88,2' sinde bağımsız dış denetimin olduğunu görmekteyiz. Bu durumda iç denetimi olmayan bazı firmaların bağımsız dış denetim yaptırdıklarını söyleyebiliriz. Bağımsız dış denetim yaptıran 15 firmanın 5 adeti 3 ayda bir, 2 adeti 6 ayda bir ve 8 adeti yılda bir denetim yaptırmaktadır.

Firmaların sermaye artırımı ile ilgili bilgilerini sorduğumuzda firmaların \%52,9'u sermaye artırımına gittiklerini, \%47,1'i sermaye artırımı yapmadıklarını belirtmektedir. Sermaye artırımına giden firmaların çoğunluğu da son yıllarda sermaye artırımına gitmişlerdir. Firmalar sermaye yapılarını güçlendirdikleri sürece kredi temininde kolaylıklarla karşılaşacaklardır.

KOBİ'lerin kredilerden yararlanma oranlarının düşük olma nedenlerinden en önemlisinin kredilerin maliyeti olduğunu belirtmektedirler. 2. önemli nedenin kredi veren kuruluşların yetersizliği, 3. önemli nedenin ekonomik krizler olduğu daha sonra sırasıyla krediye ihtiyaç duyulmaması, yurtdışı kredi temininin kolaylığı ve diğer nedenler belirtilmektedirler. Büyük firmalara düşük oranla kredi verilirken KOBİ'lere verilen kredilerde kredi oranı daha yüksek tutulmaktadır. Bunun sonucunda KOBİ'ler uygun faizde kredi temin edememe durumuyla karşı karşıya kalmaktadırlar. Ancak Basel II uygulamalarıyla bu durum daha da pekişecektir. Eğer KOBİ'ler gereken düzenlemeleri (şeffaflaşma, kayıt dışılığı azaltma vb.) yapmazlarsa kredi maliyetlerinin yüksekliği devam edecektir.

Basel II Kriterlerinin bankalara etkisinin dışında bir de reel sektöre etkileri olduğunu daha önce belirtmiştik. Firmalara Basel II Kriterlerinin reel sektöre muhtemel etkilerinin neler olabileceği konusundaki beklentileri sorulduğunda, Basel II Kriterlerinin reel sektöre muhtemel etkilerinden en önemlisinin derecelendirme gereksinimini artırması olduğu görülmektedir. 2. önemli etkinin borçlanma maliyetinin seviyesini değiştirmesi, 3. önemli etkinin kredilerde fiyat farklılaştırmasını artırması olduğunu belirtebiliriz. Kalan etkileri de şöyle sıralayabiliriz; bankalarca talep edilen verilerin kapsamını artırması, teminat türlerini değiştirmesi, yönetim yapısında değişikliğe neden olması ve diğer etkiler. Bu durumda firmaların en çok 
derecelendirme konusundan etkileneceği açıktır. Standart yaklaşımda ilk konu derecelendirme olacağından, firmaların bu konuyu dikkate alarak derecelendirmeye dahil edilecek hususlara önem vermesi gerekmektedir.

Firmaların zorlukların hepsini yaşayacaklarını düşündükleri görülmektedir. En önemli zorluğun kayıt dışılık ile ilgili sorunlar olacağı belirtilmiştir. Kayıt dışılık ile ilgili sorunların çözülmesiyle reel sektör firmaları hem daha kolay ve düşük maliyetli kredi temin edebilecekler hem de ekonomi göstergeleri olumlu etkilenecektir.

Firmaların derecelendirme ile ilgili yaşayacaklarını düşündükleri zorluklar sıralandığında, firmalar derecelendirme ile ilgili olarak en çok derecelendirme kuruluşlarının azlığının zorluk yaşatacağını, daha sonra derecelendirme ile ilgili bilgi eksiliğinin zorluk yaşatacağını ve son olarak da derecelendirmenin maliyetinin zorluk yaşatacağını beklemektedirler. $\mathrm{Bu}$ durum, ülkemizde derecelendirme kuruluşunun olmamasının etkisinin küçümsenmemesi gerektiğini göstermektedir.

Firmaların kısa ve uzun vadede Basel II'den beklentilerinin, kısa vadede firmaların \%82,4'ünün olumlu, $\% 17,6$ 'sının olumsuz olduğu görülmektedir. Orta ve uzun vadede ise bütün firmaların olumlu beklentileri olduğu sonucuna ulaşılmıştır. Basel II hakkında ilk başta firmaların olumlu beklentilerinin düşük olması normaldir. Bu kriterlerin uzun vadede yararlı olacağı firmalar açısından da ortak görüştür.

Türkiye'nin ilk 1000 büyük firması arasında olmanın verdiği güvenle firmalar Basel II'de zorluk yaşamayacaklarını düşünmektedirler. Aynı şekilde Basel II ve risk yönetimi konuları hakkında bilgiye ulaşmada firmalar zorluk yaşamayacaklarını belirtmektedirler.

Firmaların Basel II ve risk yönetimi konularında eğitimlere katılma durumları sorulduğunda firmaların \%47,1'i eğitimlere katıldıklarını, \%52,9'u herhangi bir eğitime katılmadıklarını belirtmişlerdir. Eğitime katılanların çoğunluğu bankaların Basel II hakkında verdikleri seminerler vb. eğitimlere katıldıklarını açıklamışlardır. Eğitime katılan ve katılmayanların ortak isteği, bu konudaki eğitimlerin içeriğinin firmaların faydalanabileceği şekilde geliştirilmesi ve firmaların nasıl etkileneceğinin daha çok vurgulanması gerektiği yönündedir.

Son olarak soru formunda firmaların Basel II'ye hazırlık sürecinde karşılaşabileceklerini bekledikleri engeller/kısıtlar/sorunlar vb. sıralanması istenmiştir.

Firmalar Basel II'ye hazırlık sürecinde en çok nitelikli ihtisas personeli konusunda sorun yaşayabileceklerini beklemektedirler. Daha sonra sırasıyla, Basel II'nin anlaşılamaması, maliyetlerin yüksek olması, yetersiz bütçe, muhasebesel kısıtlar ve teknoloji gelmektedir. Bu sorunların üstesinden gelinebilmesi için firmaların danışmanlardan yardım alması gerekebilir.

Basel II Kriterleri konusunda büyük firmaların pek sorun yaşamayacağı, daha küçük firmaların Basel II'den olumsuz etkilenebilecekleri düşünülmektedir. Firmalardan aldığımız bilgiler ışığında küçük ve orta büyüklükteki firmaların Basel II'ye uyum aşamasında zorluk yaşayacakları açıktır. Bu konuda geçiş sürecinde en çok yardımın KOBİ’lere yapılması gerektiği düşünülmektedir.

\subsection{BASEL III - Bankacılı Sektörü}

Basel III Kriterlerinin temelini oluşturan sermaye, likidite ve kârlılık oranlarını esas aldığımız araştırmamızda Türkiye Bankalar Birliği' nin yayınladığı verilerden analizler yapılmıştır. Türkiye'de 31 Aralık 2017 tarihi itibariyle aktif büyüklüğü sıralamasındaki ilk beş banka şöyledir:

1. Türkiye Cumhuriyeti Ziraat Bankası AŞ.

2. Türkiye İş Bankası AŞ.

3. Türkiye Garanti Bankası AŞ.

4. Akbank T.A.Ş.

5. Türkiye Halk Bankası AŞ.

Sermaye Yeterliliği Oranları: 31 Aralık 2017 konsolide finansal tablo verilerine göre aşağıdaki oranlar elde edilmiştir. 
Tablo 2: Sermaye Yeterliliği Oranları

\begin{tabular}{|l|c|c|c|c|c|}
\hline & \multicolumn{4}{l|}{ Sermaye Yeterliliği Oranı } \\
\hline & $\mathbf{2 0 1 7}$ & $\mathbf{2 0 1 6}$ & $\mathbf{2 0 1 5}$ & $\mathbf{2 0 1 4}$ & $\mathbf{2 0 1 3}$ \\
\hline Türkiye'de Bankacılık Sistemi & $\mathbf{1 6 , 8}$ & $\mathbf{1 5 , 5}$ & $\mathbf{1 5 , 6}$ & $\mathbf{1 6 , 4}$ & $\mathbf{1 5 , 4}$ \\
\hline Türkiye Cumhuriyeti Ziraat Bankası A.Ş. & 15,2 & 14,5 & 15,1 & 18,2 & 13,2 \\
\hline Türkiye Halk Bankası A.Ş. & 14,2 & 13,1 & 13,8 & 13,6 & 13,9 \\
\hline Akbank T.A.Ş. & 17,0 & 14,3 & 14,6 & 15,2 & 15,0 \\
\hline Türkiye İş Bankası A.Ş. & 16,7 & 15,2 & 15,6 & 16,0 & 14,4 \\
\hline Türkiye Garanti Bankası A.Ş. & 18,7 & 16,2 & 15,0 & 15,2 & 14,4 \\
\hline
\end{tabular}

Kaynak:https://www.tbb.org.tr/tr/bankacilik/banka-ve-sektor-bilgileri/istatistiki-raporlar/59

Sermaye yeterliliği oranlarının 2013 yılından 2017 yılına kadar artış gösterdiği görülmektedir. Garanti Bankası'nın 2017 yılında sermaye yeterliliği oranının sektör ortalamasının üstünde olduğu sonucuna ulaşılmıştır. Sermaye yeterlilik oranının yüksek olması bankaların kredilerin geri ödenmemesi durumunda daha az sıkıntı yaşayacağını ortaya koymaktadır.

Likidite Oranlart: 31 Aralık 2017 konsolide finansal tablo verilerine göre aşağıdaki oranlar elde edilmiştir.

Tablo 3: Likidite Oranları

\begin{tabular}{|l|c|c|c|c|c|}
\hline & \multicolumn{5}{|c|}{ Likit Aktifler / Kısa Vadeli Yükümlülükler } \\
\hline & $\mathbf{2 0 1 7}$ & $\mathbf{2 0 1 6}$ & $\mathbf{2 0 1 5}$ & $\mathbf{2 0 1 4}$ & $\mathbf{2 0 1 3}$ \\
\hline Türkiye'de Bankacıllk Sistemi & $\mathbf{4 4 , 8}$ & $\mathbf{4 7 , 4}$ & $\mathbf{5 0 , 6}$ & $\mathbf{5 2 , 9}$ & $\mathbf{5 4 , 1}$ \\
\hline Türkiye Cumhuriyeti Ziraat Bankası A.Ş. & 42,1 & 46,1 & 51,2 & 58,1 & 57,3 \\
\hline Türkiye Halk Bankası A.Ş. & 39,8 & 34,9 & 37,6 & 34,7 & 40,8 \\
\hline Akbank T.A.Ş. & 56,5 & 62,1 & 61,3 & 62,5 & 65,4 \\
\hline Türkiye İş Bankası A.Ş. & 44,3 & 47,4 & 53,1 & 52,4 & 46,0 \\
\hline Türkiye Garanti Bankası A.Ş. & 40,8 & 39,6 & 46,0 & 53,3 & 57,2 \\
\hline
\end{tabular}

Kaynak:https://www.tbb.org.tr/tr/bankacilik/banka-ve-sektor-bilgileri/istatistiki-raporlar/59

Likidite oranlarına baktığımızda, hem sektör ortalamaları hem de banka bazında, 2013 yılından 2017 yılına doğru azalma olduğu görülmüştür. Akbank'ın diğer bankalardan daha yüksek likidite oranlarına sahip olduğu sonucuna ulaşıllmıştır. Likidite oranı yüksek bankalar, aktiflerini daha iyi yönetebilecektir.

Kârlılık Oranları: 31 Aralık 2017 konsolide finansal tablo verilerine göre aşağıdaki oranlar elde edilmiştir.

Tablo 4: Kârlııı Oranları

\begin{tabular}{|l|c|c|c|c|c|c|c|c|c|c|}
\hline & \multicolumn{4}{|c|}{ Ortalama Aktif Kârlıı̆̆ } & \multicolumn{5}{c|}{ Ortalama Özkaynak Kârııı̆ı } \\
\hline & $\mathbf{2 0 1 7}$ & $\mathbf{2 0 1 6}$ & $\mathbf{2 0 1 5}$ & $\mathbf{2 0 1 4}$ & $\mathbf{2 0 1 3}$ & $\mathbf{2 0 1 7}$ & $\mathbf{2 0 1 6}$ & $\mathbf{2 0 1 5}$ & $\mathbf{2 0 1 4}$ & $\mathbf{2 0 1 3}$ \\
\hline $\begin{array}{l}\text { Türkiye'de Bankacılık } \\
\text { Sistemi }\end{array}$ & $\mathbf{1 , 7}$ & $\mathbf{1 , 5}$ & $\mathbf{1 , 2}$ & $\mathbf{1 , 4}$ & $\mathbf{1 , 6}$ & $\mathbf{1 4 , 9}$ & $\mathbf{1 3 , 5}$ & $\mathbf{1 0 , 8}$ & $\mathbf{1 2 , 0}$ & $\mathbf{1 3 , 1}$ \\
\hline $\begin{array}{l}\text { Türkiye Cumhuriyeti } \\
\text { Ziraat Bankası A.Ş. }\end{array}$ & 2,0 & 2,0 & 1,9 & 1,8 & 1,8 & 18,6 & 18,8 & 17,2 & 17,3 & 18,7 \\
\hline Türkiye Halk Bankası A.Ş. & 1,4 & 1,2 & 1,3 & 1,5 & 2,2 & 16,0 & 12,6 & 12,9 & 14,4 & 20,8 \\
\hline Akbank T.A.Ş. & 2,1 & 1,8 & 1,4 & 1,6 & 1,7 & 17,0 & 15,8 & 11,6 & 13,6 & 13,6 \\
\hline Türkiye İş Bankası A.Ş. & 1,6 & 1,6 & 1,2 & 1,5 & 1,6 & 13,4 & 13,8 & 10,1 & 12,8 & 13,7 \\
\hline $\begin{array}{l}\text { Türkiye Garanti Bankası } \\
\text { A.Ş. }\end{array}$ & 2,1 & 1,9 & 1,4 & 1,5 & 1,7 & 16,5 & 15,2 & 12,0 & 13,2 & 13,7 \\
\hline
\end{tabular}

Kaynak:https://www.tbb.org.tr/tr/bankacilik/banka-ve-sektor-bilgileri/istatistiki-raporlar/59

Kârlılık oranlarına baktığımızda, bankaların sektör ortalamalarında veya üstünde oldukları tespit edilmiştir. Ziraat Bankası'nın özkaynak karlılığı, Garanti Bankası'nın ise aktif karlılığı diğer bankalara kıyasla daha yüksektir. Karlılık oranlarının yüksek olması temelde bankaların mevduat ve kredi faizleri arasındaki farkın yüksek olmasından kaynaklanmaktadır. 


\section{SONUÇ VE TARTIŞMA}

Basel II kriterleri hem firmalar hem de bankalar açısından faydalı olacaktır. Firmalar öncelikle derecelendirme notlarının yükselmesi için kayıt dışılık gibi uygulamaları sonlandırmak zorunda kalacaklar, bankalar da derecelendirme neticesinde daha az riskli firmaları belirleyerek kredi kullandırabileceklerdir.

Yaptığımız çalışmada da görülmektedir ki, firmalar ne kadar güçlü ise Basel II'den çekinceleri o kadar azdır. Ancak, ülkemizde daha çok KOBİ'lerin mevcut olduğu düşünülecek olursa, bu kriterlerin uygulanmasının zorlu geçeceği açıktır. Araştırmamıza katılan firmalar, Kayseri'nin en büyük firmalarından ve Türkiye'nin ilk 1000 firması arasındaki firmalardan oldukları için Basel II ile ilgili herhangi bir problem yaşayacaklarını düşünmemektedirler. Bu firmaların yetkililerinin araştırmamız sırasındaki görüşleri, büyük firmaların değil küçük ve orta büyüklükteki firmaların Basel II kriterlerinden olumsuz etkilenecekleri yönündedir.

İşletmeler, finansal tablolarının şeffaflığı, finansal yapılarının gücü, kurumsal yönetişimleri, risk yönetim seviyeleri gibi konular dikkate alınarak standart yaklaşımda bağımsız derecelendirme kuruluşlarınca, içsel derecelendirmeye dayalı yaklaşımlarda ise bankalar tarafından derecelendirmeye tabi tutulacaklardır. Yüksek kredi notu alan firmalar daha az kredi maliyeti ile kredi temini olanağına sahip olabileceklerdir. Fakat, Türkiye'deki firmalar incelendiğinde, işletme sermayelerinin yetersiz olduğu, kayıt dış1lık nedeniyle yeterince şeffaf olamadıkları, aile şirketlerinin çokluğu nedeniyle kurumsal yönetişimin sağlanamadığı, kalifiye personelin (özellikle risk yönetimi ve finansal yönetim konularında) bulunmadığı gözlenmektedir.

Basel II kriterlerinin da uygulanmaya başlamasıyla firmaların kredi temini için kendi bünyelerinde köklü değişimlere gitmeleri gerekmektedir. Firmalara şu önerilerde bulunabiliriz;

Kalifiye personelle çalışmaya başlanması

Sigortasız işçi çalıştırılmasına son verilmesi

Finansal yapılarının güçlendirilmesi

Faaliyetlerini kayıt altına alarak finansal tabloların sunulması

Kurumsal yönetim kültürünün oluşturulması

Basel II uygulamalarında dikkat edilmesi gereken diğer bir konu ise teminattır. Firmalar genellikle müşteri çek ve senedi, gayrimenkul ipotekleri kullanırken, Basel II kapsamında bu tür teminatlar risk azaltıcı unsur olarak görülmedikleri için kredi teminatı olma özelliğinde değildirler. Bu durumda firmalar teminat konusunda sıkıntı yaşayabileceklerdir. Firmaların en kısa sürede teminatlarını değiştirmeleri gerekmektedir. Özellikle Basel II'de konut ipoteği karşılığında kredi temin etmek firmalara avantajlar sağlayacaktır. Firmaların bu konuya gereken önemi göstermeleri büyük önem taşımaktadır.

Çalışmaya katılan firmaların kayıt dışılık, kamuya açıklık vb sorunları olmadığı için ve gelir tablosubilanço gibi verilerine güvendikleri için Basel II uygulanacağı zaman kredi alımında sorun yaşamayacakları çok açıktır. Ancak, KOBİ olarak tanımlanan firmaların kredi alımında birçok problemle karşılaşacakları ya da kredi maliyetlerinin büyük firmalara oranla çok daha fazla olacağı belirtilmektedir.

Firmalar, belirtilen tedbirleri aldıkları takdirde Basel II uygulamalarında sorun yaşamayacaklar ve uluslararası piyasalardan bile rahatlıkla kredi temin edebileceklerdir. Basel II uygulamalarının avantajını iyi değerlendiren firmalar bu durumdan kârlı çıkacaklardır. Firmalar önerileri dikkatle uyguladıklarında Basel II'den kaynaklanan tehditleri firsat haline dönüştürebileceklerdir.

Basel III Kriterlerinin finans sektörünü temelde sermaye yönünden etkilediği belirtilmiştir. Bankacılık sektöründe finansal tablolardan elde edilen veriler neticesinde Basel III düzenlemelerine ne kadar uyum sağlandığı incelenmiştir. Türkiye'deki bankaların 31 Aralık 2017 tarihi itibariyle aktif büyüklük sıralamasındaki ilk beş banka esas alınarak çalışmalar yapılmıştır.

Bankaların sermaye, likidite ve karlılık oranlarının sektör ortalamalarının üstünde olması Basel III Kriterlerine uygunluğunu göstermektedir. Çalışmamızdaki bankaların oran analizleri olumlu olarak görülse de piyasa koşulları, dış ekonomik etkenler dikkate alınarak değerlendirilmelidir.

Ülkemiz bankacılık sistemi Basel Kriterlerini finansal sistem içerisinde uygulamaktadır. Bankacılık sisteminin krizlere karşı daha güçlü olması ve daha etkin finansal destek sağlaması amaçlanmaktadır. Türkiye 2013 yılından itibaren Basel III Kriterlerini kademeli şekilde uygulamakta olup, 2019 y1lında sürecin tamamlanması beklenmektedir. 


\section{KAYNAKÇA}

Ateş, Alişan, (2003) “Bankalarda Üstlenilen Riskler ve Türk Bankacılık Sisteminin Basel Kriterlerine Uyumu”, Yüksek Lisans Tezi,

Balc1, Baki Rıza, (2011) “The Nexus Between Basel II and IFRS for SMEs”, Journal of Yasar University, 21 (6), 3471 3479.

Bartolini, Monica, Silvia Gardini \& Giuseppe Savioli, (2014) "International Financial Reporting Standards and SMEs: The Effects on Firm Rating According to Basel II", International Journal of Accounting, Auditing and Performance Evaluation, 10 (1), 43-67.

Beşinci, Murat, "Basel Kriterleri, Basel II'nin Finans ve Bankacılık Sektörüne Etkileri ve Türk Bankacılık Sektörünün Basel II'ye Uyum Süreci”, Active Dergisi, 25.01.2019

Cangürel, Ozan ve diğ., (2010) Sorularla Basel III. BDDK Risk Yönetim Dairesi, Ankara.

Dedu, Vasile \& Dan Costin Nitescu, (2012) "Basel III-Between Global Thinking and Local Acting, Theoretical and Applied Economics", 19 (6), 5-12.

Demirkol, Ömer Faruk ve Emel Aba, (2012) "BASEL II Sermaye Yeterliliği Uzlaşısı Süreci İçinde Gelen Ek Düzenlemeler Seti: BASEL III Kriterleri”, Niğde Üniversitesi İİBF Dergisi, 5 (2), 253-265.

Demirkol, Ömer Faruk ve Emel Şenbayram, (2014) “Basel III Uzlaşısı ve Makroekonomik Boyutu”, KSÜ Sosyal Bilimler Dergisi (KSÜ Journal of Social Science), 11 (2), 245-262.

Doğan, Burcu ve Erkan Sarsıc1, (2018) “Basel III ve Kobi’ler Üzerine Muhtemel Etkileri”, Balkan ve Yakın Doğu Sosyal Bilimler Dergisi, 04 (02), 110-116.

Küçüközmen, Coşkun, (2007) Basel II, Kastamonu Ticaret Borsası. Kastamonu.

Sungur, Gökhan ve Abdurrahman Okur, (2014) "Basel Kriterleri ve KOBİler Tarafından Anlaşılmasına Yönelik Uygulama Çalışması”, Bankacılık ve Finansal Araştırmalar Dergisi, Sayı 1, 11-23.

Şendoğdu, Aslan, (2010) "Basel II Kriterlerinin Dünü Bugünü ve Gelecek İçin Bir Üst Sürümüne Olan İhtiyacın Kaçınılmazlığı”, Bankacılık ve Sigortacılık Araştırmaları Dergisi, 1 (2), 4-13.

Yüksel, Ayhan, (2005). Basel II nin KOBİ Kredilerine Muhtemel Etkileri. BDDK Araştırma Dairesi. Ankara

Yayla, Münür ve Yasemin Türker Kaya, (2005). "Basel-II, Ekonomik Yansımaları ve Geçiş Süreci”, BDDK ARD Çalışma Raporları: 2005/3, 1-52.

Türkiye Bankalar Birliği İstatistiki Raporlar, Erişim Tarihi: 20.01.2019

Ziraat Bankası Eğitim Daire Başkanlığı. (2005). Basel II (Yeni Sermaye Yeterliliği Düzenlemesi). Ankara. 